\title{
Faktor-Faktor Kecemasan Tenaga Kesehatan Selama Pandemi COVID-19
}

\author{
TYARA ADERALDA DEMINANGA*, AZIZAH MUSLIHA FITRI, ARGA BUNTARA, \& DYAH UTARI \\ Program Studi Kesehatan Masyarakat, Universitas Pembangunan Nasional Veteran Jakarta
}

\begin{abstract}
ABSTRAK
Salah satu dampak dari pandemi COVID-19 adalah meningkatnya prevalensi kecemasan tenaga kesehatan. Penelitian ini bersifat analisis kuantitatif dengan desain studi cross-sectional. Sebanyak 167 tenaga kesehatan yang bekerja di RSUD Pasar Rebo direkrut sebagai sampel menggunakan teknik convenience sampling. Pengumpulan data dilakukan menggunakan kuesioner Zung Self-Rating Anxiety Scale yang disebarkan secara daring. Data dianalisis dengan menggunakan uji Chi Square. Hasil analisis menunjukkan bahwa terdapat hubungan yang bermakna antara jenis kelamin, usia, status pernikahan, status memiliki anak, bekerja sebagai perawat, dan beban kerja berat dengan tingkat kecemasan pada tenaga kesehatan. Diharapkan rumah sakit dapat mengambil upaya khusus untuk menjaga kesehatan mental tenaga kesehatan seperti memberikan konsultasi, mensosialisasikan mekanisme coping yang efektif pada tenaga kesehatan.
\end{abstract}

Kata kunci: COVID-19, kecemasan, tenaga kesehatan

\begin{abstract}
One of the impacts of the COVID-19 pandemic is the increasing prevalence of anxiety in health workers. This study is a quantitative analysis with a cross-sectional study design. A total of 167 health workers working at Pasar Rebo Hospital were recruited as a sample using convenience sampling technique. Data was collected using the Zung Self-Rating Anxiety Scale questionnaire which was distributed online. Data were analyzed using Chi Square test. The results of the analysis showed that there was a significant relationship between gender, age, marital status, status of having children, working as a nurse, and heavy workload with anxiety levels in health workers. It is hoped that hospitals can take special efforts to maintain the mental health of health workers such as providing consultations, socializing effective coping mechanisms to health workers.
\end{abstract}

Keywords: anxiety, COVID-19, healthcare workers

INSAN Jurnal Psikologi dan Kesehatan Mental, 2021, Vol. 6(2), 127-137, doi: 10.20473/jpkm.v6i22021.127-137 Dikirimkan: 3 November 2020 Diterima: 28 November 2021 Diterbitkan: 1 Desember 2021

Editor: Rizqy Amelia Zein

*Alamat korespondensi: Jl. Raya Limo, Kecamatan Limo, Kota Depok, Jawa Barat 16515. Pos-el:

tyaraaderaldad@upnvj.ac.id

Naskah ini merupakan naskah dengan akses terbuka dibawah ketentuan the Creative Common Attribution License (http://creativecommons.org/licenses/by/4.0), sehingga penggunaan, distribusi, reproduksi dalam media apapun atas artikel ini tidak dibatasi, selama sumber aslinya disitir dengan baik. 


\section{PEN D A H U L U A N}

Coronavirus Disease-19 (COVID-19) adalah penyakit pernapasan yang disebabkan oleh virus SARS-CoV2 (World Health Organization (WHO), 2020a). Penyakit ini pertama kali terdeteksi di China dan sekarang telah menyebar secara global, termasuk ke Indonesia. Per 4 Juli 2021, World Health Organization (WHO) melaporkan terjadi kenaikan jumlah kasus positif COVID-19 sebesar 3 persen (2.668.561 kasus) dalam konteks global. WHO melaporkan bahwa pada regional Asia Tenggara, per 4 Juli 2021 terjadi peningkatan kasus positif sebesar 7 persen (612.933 kasus) dibandingkan dengan data satu minggu sebelumnya (World Health Organization (WHO), 2020a). Grafik persebaran kasus positif COVID-19 di Indonesia per hari yang dihimpun oleh Peta Sebaran COVID-19 menunjukkan bahwa sampai 10 Juli 2021 terjadi penambahan kasus paling banyak di provinsi Daerah Khusus Ibukota (DKI) Jakarta yaitu 649.302 kasus (Satgas COVID-19, 2021). Berdasarkan grafik data surveilans yang dikeluarkan oleh WHO dapat diketahui bahwa tren kasus positif COVID-19 di Indonesia mengalami peningkatan (World Health Organization (WHO), 2020a). Data COVID-19 per 4 Juli 2021 menyatakan bahwa jumlah kasus aktif masih menunjukkan tren kenaikan. Selama satu minggu terhitung dari 28 Juni sampai dengan 4 Juli 2021, incidence rate COVID-19 di Indonesia adalah 46,9 per 100.000 penduduk Indonesia (World Health Organization (WHO), 2020a).

Wabah COVID-19 menyebabkan terjadinya perubahan mengenai sistem kerja rumah sakit. Semakin banyaknya kasus yang terkonfirmasi berarti semakin tinggi permintaan terhadap layanan kesehatan (Bao, dkk., 2020). Kecemasan adalah dampak psikologis yang paling umum ditemukan sebagai akibat dari pandemi COVID-19. Kecemasan paling banyak ditemukan terjadi pada tenaga kesehatan yang bekerja di rumah sakit (Noor, dkk., 2021). Tenaga kesehatan mengalami kecemasan disebabkan oleh situasi baru yang harus mereka hadapi sehingga menimbulkan perubahan dalam rutinitas di tempat kerja maupun dalam kehidupan sehari-hari (Mattila, dkk., 2020). Kecemasan yang dialami oleh tenaga kesehatan merupakan gangguan psikologis yang masih dalam tahap awal sehingga masih mungkin untuk ditangani (Handayani, dkk., 2020). Pandemi COVID-19 yang masih terus terjadi, jumlah kasus yang semakin meningkat, hingga keterbatasan perawatan. Hal-hal ini membuat petugas kesehatan di fasilitas pelayanan Kesehatan (Fasyankes) yang ada di garda depan bekerja tanpa mengenal lelah dan terus melakukan pelayanan hingga menimbulkan kelelahan fisik dan berpotensi menimbulkan tekanan psikologis baik kecemasan, rasa takut stres hingga depresi (Kementerian Kesehatan, 2020a).

Satu dari lima penduduk Indonesia yang terdampak COVID-19 mengalami kecemasan (Anindyajati, dkk., 2021). Penelitian yang dilakukan di Kota Pontianak menunjukkan bahwa tenaga kesehatan yang menangani pasien COVID-19 memiliki risiko lebih tinggi mengalami kecemasan, depresi, dan insomnia (Hanggoro, dkk., 2020). Hasil penelitian yang dilakukan terhadap tenaga kesehatan di Rumah Sakit Dr. Soetomo, Surabaya dari 10-16 Juni 2020 menunjukkan dari 227 responden yang terlibat sebanyak 33 persen mengalami kecemasan parah (Setiawati, dkk., 2021). Faktor sosial yang memiliki hubungan dengan tingginya kecemasan pada tenaga kesehatan yaitu tinggal dengan orang yang sudah lansia, memiliki penyakit yang bersifat kronis, kekebalan tubuh menurun atau memiliki gangguan pada sistem pernafasan (Alenazi, dkk., 2020).

Faktor risiko yang ditemukan dan memiliki hubungan kuat dengan kejadian kecemasan pada tenaga kesehatan yaitu peningkatan beban kerja, gangguan pada sistem pernafasan, telah melakukan tes COVID-19, memiliki anggota keluarga yang sedang dirawat, strategi coping yang negatif, dan kelelahan kerja (Jie, dkk., 2020). Penelitian lain memberikan hasil bahwa ketersediaan alat pelindung diri merupakan faktor yang memiliki pengaruh paling kuat terhadap kecemasan tenaga kesehatan (Fadli, dkk., 2020). Penelitian ini difokuskan di Rumah Sakit Umum Daerah Pasar Rebo, yang juga merupakan salah satu rumah sakit rujukan untuk pasien COVID-19 di wilayah DKI Jakarta. Berdasarkan latar belakang dan permasalahan yang telah dijelaskan diatas, penelitian dengan tujuan menemukan faktor-

INSAN Jurnal Psikologi dan Kesehatan Mental

2021, Vol. 6(2), 127-137

doi: 10.20473/jpkm.v6i22021.127-137 
faktor yang berhubungan dengan tingkat kecemasan pada tenaga kesehatan di RSUD Pasar Rebo selama pandemi COVID-19 tahun 2021 penting untuk dilakukan.

\section{Desain Penelitian}

\section{E T O D E}

Penelitian ini bersifat analisis kuantitatif dengan desain studi cross-sectional. Pemilihan desain studi disesuaikan dengan tujuan penelitian yaitu untuk menemukan faktor-faktor yang berhubungan dengan tingkat kecemasan pada tenaga kesehatan di RSUD Pasar Rebo selama pandemic COVID-19 tahun 2021.

\section{Partisipan}

Partisipan dalam penelitian ini adalah tenaga kesehatan yang bekerja di RSUD Pasar Rebo, Jakarta Timur. Dalam memilih partisipan, penulis menggunakan teknik convenience sampling. Dari 632 tenaga kesehatan, sebanyak 167 partisipan mengisi kuesioner yang disebarkan secara daring. Sebelum mengisi kuesioner, partisipan diberikan waktu untuk membaca terlebih dahulu naskah penjelasan sebelum persetujuan kemudian mencentang pilihan bersedia sebagai partisipan penelitian. Untuk menguji hipotesis penelitian, penulis merekrut 167 partisipan, yang merupakan tenaga kesehatan yang aktif bekerja di RSUD Pasar Rebo, Jakarta Timur. Dari 167 partisipan tersebut, 65,3 persen usia tua; 75,4 persen perempuan; 100 persen memiliki tingkat pendidikan tinggi; 82 persen memiliki tingkat penghasilan diatas Upah Minimum Regional (UMR) DKI Jakarta; 69,5 persen bekerja sebagai perawat; 79 persen telah menikah; 73,1 persen telah memiliki anak.

\section{Pengukuran}

Beban kerja yang berlebihan dapat menyebabkan timbulnya masalah kesehatan seperti terluka, kecelakaan kerja, hingga masalah mental seperti depresi dan kecemasan (Yuli Asih, dkk., 2018). Terdapat dua faktor utama yang memengaruhi beban kerja yaitu faktor eksternal dan faktor internal (Tarwaka, dkk., 2004). Peneliti menjadikan teori ini sebagai landasan dalam membuat skala beban kerja. Skala yang dibuat merupakan skala Likert dengan empat pilihan jawaban alternatif dan memiliki 10 butir pernyataan, dengan reliabilitas sebesar $\alpha=0,755$.

Kecemasan adalah istilah yang umum digunakan untuk mendeskripsikan perasaan yang normal terjadi saat seseorang berhadapan dengan ancaman, bahaya, atau kondisi stres. Kecemasan terjadi saat seseorang merasakan gelisah, tidak nyaman dan tegang (Craske, dkk., 2011). Cemas dan takut adalah perasaan yang umum ditemukan dalam kehidupan sehari-hari. Perasaan ini akan dikategorikan sebagai sesuatu yang salah ketika situasi yang dihadapi oleh seseorang sebenarnya tidak mengancam, namun reaksi yang diberikan berlebihan (Safaria, 2021). Dalam penelitian ini, peneliti menggunakan Zung SelfRatin Anxiety Scale dengan skala Likert yang terdiri dari 20 butir. Untuk analisis bivariat, peneliti akan mengkategorikan skor dari Zung Self-Rating Anxiety Scale kedalam dua kategori berbeda ("cemas" dan "tidak cemas") berdasarkan nilai median.

WHO merekomendasikan jenis-jenis alat pelindung diri (APD) yang wajib digunakan saat menangani pasien COVID-19 yaitu; sarung tangan, masker medis/bedah, kacamata, pelindung wajah dan jubah serta alat-alat respirator dan apron (World Health Organization (WHO), 2020). Hasil penelitian yang dilakukan oleh Fadli, dkk. (2020) mengemukakan bahwa ketersediaan APD merupakan faktor risiko yang paling memiliki hubungan dengan kejadian kecemasan pada tenaga kesehatan. Peneliti menjadikan standar yang disusun oleh Satuan Tugas (SATGAS) COVID-19 sebagai landasan utama

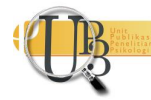


dalam menyusun skala Ketersediaan APD. Skala ini menggunakan skala Likert dengan empat pilihan jawaban dan terdiri dari 8 butir pernyataan dimana hasil reliabilitas menunjukkan $\alpha=0,725$.

\section{Analisis Data}

Analisis data dilakukan secara univariat (untuk mengetahui distribusi frekuensi) dan bivariat (untuk mengetahui hubungan antarvariabel). Analisis bivariat dilakukan dengan uji Chi Square mengunakan SPSS versi 25.

\section{HAS I L P EN ELIT IAN}

Hasil dari penelitian ini menunjukkan bahwa dari 167 partisipam, sebanyak 87 (52 persen) partisipan mengalami kecemasan dan 80 partisipan tidak mengalami kecemasan. Sesuai dengan temuan penelitian yang disajikan dalam Tabel 1, dapat diketahui bahwa jenis kelamin perempuan berhubungan signifikan dengan kecemasan $(O R=2,656 ; 95 \%$ CI $[1,272 ; 5,546] ; p=0,014)$, usia muda $(O R=2,079 ; 95 \%$ CI $[1,080$; 4,001]; $p=0,041)$, beban kerja berat $(O R=2,727 ; 95 \%$ CI $[1,444 ; 5,148] ; p=0,003)$. Sedangkan status pernikahan $(O R=0,418 ; 95 \% \mathrm{CI}[0,190 ; 0,923] ; p=0,045)$, status memiliki anak $(O R=0,438 ; 95 \% \mathrm{CI}$ $[0,215 ; 0,896] ; p=0,034)$, perawat $(O R=0,475 ; 95 \%$ CI $[0,241 ; 0,938] ; p=0,046)$, merupakan faktor protektif kecemasan. Terkait dengan variabel lainnya yaitu tingkat penghasilan, shift kerja, kontak dengan pasien COVID-19, dan ketersediaan APD tidak ditemukan memiliki hubungan dengan tingkat kecemasan tenaga kesehatan.

Tabel 1. Hubungan Antara Variabel Independen dengan Tingkat Kecemasan

\begin{tabular}{|c|c|c|c|c|c|c|c|c|}
\hline \multirow{3}{*}{ Variabel } & \multicolumn{6}{|c|}{ Tingkat Kecemasan } & \multirow{3}{*}{ Nilai p } & \multirow{3}{*}{$\begin{array}{c}\text { OR } \\
95 \% \text { CI }\end{array}$} \\
\hline & \multicolumn{2}{|c|}{ Cemas } & \multicolumn{2}{|c|}{ Tidak Cemas } & \multicolumn{2}{|c|}{ Total } & & \\
\hline & $\mathbf{n}$ & $\%$ & $\mathbf{n}$ & $\%$ & $\mathbf{N}$ & $\%$ & & \\
\hline \multicolumn{9}{|l|}{ Jenis Kelamin } \\
\hline Perempuan & 73 & 57,9 & 53 & 42,1 & 126 & 100 & $0,014^{*}$ & 2,656 \\
\hline Laki-laki & 14 & 34,1 & 27 & 65,9 & 41 & 100 & & $(1,272-5,546)$ \\
\hline \multicolumn{9}{|l|}{ Usia } \\
\hline Muda & 37 & 63,8 & 21 & 36,2 & 58 & 100 & $0,041^{*}$ & 2,079 \\
\hline Tua & 50 & 45,9 & 59 & 54,1 & 109 & 100 & & $(1,080-4,001)$ \\
\hline \multicolumn{9}{|c|}{ Status Pernikahan } \\
\hline Menikah & 63 & 47,7 & 69 & 52,3 & 132 & 100 & $0,045^{*}$ & 0,418 \\
\hline Belum Menikah & 24 & 68,6 & 11 & 31,4 & 35 & 100 & & $(0,190-0,923)$ \\
\hline \multicolumn{9}{|l|}{ Status Memiliki } \\
\hline \multicolumn{9}{|l|}{ Anak } \\
\hline Memiliki Anak & 57 & 46,7 & 65 & 53,3 & 122 & 100 & $0,034^{*}$ & 0,438 \\
\hline Tidak Memiliki & 30 & 66,7 & 15 & 33,3 & 45 & 100 & & $(0,215-0,896)$ \\
\hline Anak & & & & & & & & \\
\hline \multicolumn{9}{|l|}{ Bidang Pekerjaan } \\
\hline \multicolumn{9}{|l|}{ Nakes } \\
\hline Perawat & 54 & 46,6 & 62 & 53,4 & 116 & 100 & $0,046^{*}$ & 0,475 \\
\hline Nakes lainnya & 33 & 64,7 & 18 & 35,3 & 51 & 100 & & $(0,241-0,938)$ \\
\hline \multicolumn{9}{|l|}{ Tingkat } \\
\hline \multicolumn{9}{|l|}{ Penghasilan } \\
\hline Dibawah UMR & 18 & 60 & 12 & 40 & 30 & 100 & 0,450 & 1,478 \\
\hline
\end{tabular}




\begin{tabular}{|c|c|c|c|c|c|c|c|c|}
\hline \multirow{3}{*}{ Variabel } & \multicolumn{6}{|c|}{ Tingkat Kecemasan } & \multirow{3}{*}{ Nilai p } & \multirow{3}{*}{$\begin{array}{c}\text { OR } \\
95 \% \text { CI }\end{array}$} \\
\hline & \multicolumn{2}{|c|}{ Cemas } & \multicolumn{2}{|c|}{ Tidak Cemas } & \multicolumn{2}{|c|}{ Total } & & \\
\hline & $\mathbf{n}$ & $\%$ & $\mathbf{n}$ & $\%$ & $\mathbf{N}$ & $\%$ & & \\
\hline Diatas UMR & 69 & 50,4 & 68 & 49,6 & 137 & 100 & & $(0,662-3,302)$ \\
\hline \multicolumn{9}{|l|}{ Beban Kerja } \\
\hline Berat & 61 & 62,2 & 37 & 37,8 & 98 & 100 & $0,003^{*}$ & 2,727 \\
\hline Ringan & 26 & 37,7 & 43 & 62,3 & 69 & 100 & & $(1,444-5,148)$ \\
\hline \multicolumn{9}{|l|}{ Shift Kerja } \\
\hline Shift & 59 & 52,7 & 53 & 47,3 & 112 & 100 & 0,960 & 1,073 \\
\hline Non shift & 28 & 50,9 & 27 & 49,1 & 55 & 100 & & $(0,56-2,048)$ \\
\hline \multicolumn{9}{|l|}{ Kontak dengan } \\
\hline \multicolumn{9}{|l|}{ Pasien COVID-19 } \\
\hline Pernah & 84 & 54,2 & 71 & 54,8 & 155 & 100 & 0,099 & 3,549 \\
\hline Tidak Pernah & 3 & 25 & 9 & 75 & 12 & 100 & & $(0,925-13,613)$ \\
\hline \multicolumn{9}{|l|}{ Ketersediaan APD } \\
\hline Belum Mencukupi & 46 & 57,3 & 31 & 42,7 & 77 & 100 & 0,094 & 1,773 \\
\hline Mencukupi & 41 & 43,8 & 49 & 56,3 & 90 & 100 & & $(0,958-3,284)$ \\
\hline
\end{tabular}

\section{I S K U S I}

Berdasarkan hasil penelitian, diketahui bahwa jenis kelamin perempuan memiliki hubungan dengan kecemasan tenaga kesehatan. Hasil penelitian ini sejalan dengan penelitian yang menyebutkan bahwa tenaga kesehatan perempuan ditemukan mengalami masalah gangguan kesehatan mental yang lebih parah jika dibandingkan dengan tenaga kesehatan laki-laki (Major \& Hlubocky, 2021). Perasaan cemas pada perempuan disebabkan oleh fluktuasi level dari hormon yang hanya ada pada perempuan yaitu hormon progesteron dan estrogen terutama dalam siklus menstruasi. Keberadaan hormon ini bisa menyebabkan timbulnya kecemasan secara signifikan pada perempuan (Jalnapulkar, dkk., 2018). Tidak hanya itu, namun perempuan juga memiliki peran ganda karena harus bekerja dan juga mengurus keluarga di rumah. Oleh sebab itu, perempuan dilaporkan mengalami kecemasan yang lebih tinggi jika dibanding oleh laki-laki (International Labour Organization (ILO), 2020).

Diketahui pula bahwa usia memiliki hubungan dengan tingkat kecemasan tenaga kesehatan. Hasil serupa ditemukan dalam penelitian yang dilakukan di Sidrap, Sulawesi Selatan memberikan hasil bahwa usia memiliki hubungan dengan kejadian kecemasan pada tenaga kesehatan. Dimana usia memiliki hubungan terhadap teknik coping kecemasan yang dilakukan oleh seseorang (Fadli, dkk., 2020). Hasil penelitian tersebut juga sama dengan hasil penelitian Mattila, dkk. (2020) yang dilakukan di Finlandia dimana hasil penelitian menjelaskan bahwa tenaga kesehatan yang berusia muda adalah salah satu faktor risiko kecemasan. Dalam penelitian tersebut diketahui bahwa tenaga kesehatan berusia muda mengalami kecemasan yang tinggi dibandingkan tenaga kesehatan yang berusia tua. Maturitas atau kematangan individu akan memengaruhi bagaimana mekanisme koping kecemasan yang dipilih oleh individu tersebut untuk mengatasi kecemasan. Seseorang yang masuk dalam usia tua (matur) ditemukan sukar mengalami kecemasan disebabkan karena mereka yang berusia tua memiliki kemampuan adaptasi yang jauh lebih baik terhadap perubahan situasi dibandingkan mereka yang berusia muda. Hal ini dapat dibuktikan dari hasil penelitian bahwa usia yang tua kecemasannya jauh lebih rendah dibandingkan usia yang muda (Stuart \& Laraia, 2007).

Tenaga kesehatan yang telah menikah diketahui sebagai faktor protektif terhadap kecemasan. Hasil ini sejalan dengan penelitian yang dilakukan di Trinidad dan Tobago yang menjelaskan bahwa status pernikahan tenaga kesehatan memiliki dampak terhadap kesehatan mental tenaga kesehatan sehingga

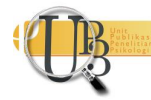


memberikan efek protektif. Dukungan yang diberikan oleh pasangan (suami atau istri) ditemukan memberikan dampak yang efektif untuk membantu meringankan beban mental yang dialami oleh tenaga kesehatan selama bekerja di rumah sakit (Nayak, dkk., 2021). Hasil pada penelitian ini tidak sejalan dengan penelitian yang menjelaskan bahwa peneliti tidak menemukan hubungan bukti yang kuat bahwa status pernikahan menyebabkan suatu perubahan dalam upaya seorang tenaga kesehatan untuk beradaptasi terhadap situasi pandemi (Preti, dkk., 2020). Hasil ini didukung oleh penelitian yang dilakukan oleh Alenazi, dkk. (2020) di Saudi Arabia yang menjelaskan bahwa dalam penelitian mereka ditemukan bahwa tenaga kesehatan yang belum menikah memiliki tingkat kecemasan yang lebih tinggi. Dari hasil uji statistik diketahui bahwa ada hubungan antara variabel status pernikahan dengan variabel tingkat kecemasan. Adanya hubungan ini dipengaruhi oleh faktor dukungan keluarga (dalam hal ini pasangan suami atau istri). Jika pasangan memberikan dukungan, maka tenaga kesehatan akan merasa jauh lebih baik sehingga beban mental berkurang.

Dalam penelitian ini, diketahui bahwa status memiliki anak adalah faktor protektif terhadap kecemasan tenaga kesehatan. Penelitian ini sejalan dengan pernyataan bahwa tenaga kesehatan yang memiliki anak di rumah ditemukan mengalami tingkat gangguan kesehatan mental yang rendah jika dibandingkan dengan dengan rekan kerja mereka yang tidak memiliki anak (Evanoff, dkk., 2020). Hasil ini didukung oleh hasil penelitian yang menjelaskan bahwa variabel memiliki anak dapat berperan sebagai faktor protektif. Faktor protektif ini melindungi tenaga kesehatan dari mengalami gangguan kesehatan mental sehingga tenaga kesehatan dapat fokus untuk menjalani pekerjaan dan kehidupan dengan baik (Walton, dkk., 2020).

Tenaga kesehatan yang bekerja sebagai perawat diketahui sebagai faktor protektif kecemasan. Berdasarkan hasil penelitian diketahui bahwa perawat memiliki pengetahuan yang jauh lebih baik dibandingkan tenaga kesehatan lainnya mengenai COVID-19. Hal ini disebabkan karena perawat ikut membantu dokter dan aktif terlibat secara langsung untuk menangani pasien COVID-19 (Kamacooko, dkk., 2021). Semakin tinggi pengetahuan tenaga kesehatan, maka akan semakin tinggi upaya pencegahan COVID-19 yang dilakukan. Hal ini dibuktikan melalui penelitian yang dilakukan di Turki terhadap 251 tenaga kesehatan (Arslanca, dkk., 2021). Diketahui bahwa memiliki pengetahuan yang baik mengenai COVID-19 adalah salah satu faktor yang memberikan efek protektif bagi kesehatan mental tenaga kesehatan (Yildirim, dkk., 2020).

Tingkat penghasilan tenaga kesehatan dalam penelitian ini diketahui tidak memiliki hubungan dengan kejadian kecemasan. Pemerintah Indonesia juga memberikan insentif kepada tenaga kesehatan yang merawat pasien COVID-19 sebagai bentuk penghargaan atas dedikasi dan kerja keras mereka (Kementerian Kesehatan, 2020b). Dalam penelitian ini tidak ditemukan hubungan antara penghasilan dengan tingkat kecemasan pada tenaga kesehatan. Tidak ditemukan hubungan disebabkan oleh sebagian besar tenaga kesehatan sebanyak 137 dari 167 responden memiliki pendapatan diatas UMR DKI Jakarta.

Sebanyak 98 tenaga kesehatan memiliki beban kerja yang dikategorikan sebagai beban kerja berat dan beban kerja diketahui berkaitan dengan dengan kecemasan. Hal ini juga sesuai dengan teori yang menyatakan bahwa beban kerja yang berlebihan dapat menyebabkan timbulnya masalah kesehatan seperti terluka, kecelakaan kerja, hingga masalah mental seperti depresi dan kecemasan (Yuli Asih, dkk., 2018). Gangguan kesehatan mental seperti depresi, kecemasan dan stres merupakan masalah-masalah yang umum ditemukan di tempat kerja. WHO menerangkan bahwa beban kerja memiliki hubungan terhadap gangguan kesehatan mental pekerja (World Health Organization (WHO), 2005). Beban kerja merupakan salah satu tekanan psikososial bagi tenaga kesehatan yang bekerja selama masa pandemi COVID-19. Beban kerja yang berat menyebabkan tenaga kesehatan mengalami stress yang menyebabkan kondisi kesehatan menurun. Hal ini menyebabkan tenaga kesehatan merasa rentan dan 
tidak berdaya karena harus dituntut untuk menyelesaikan pekerjaan mereka (Kementerian Kesehatan, 2020a).

Tidak ditemukan hubungan antara shift kerja dengan tingkat kecemasan disebabkan oleh tenaga kesehatan yang memiliki sistem kerja shift telah memiliki toleransi dalam tubuhnya yang dikenal sebagai shift work tolerance (SWT) sehingga mereka mampu bertahan untuk melakukan pekerjaan shift tanpa muncul masalah kesehatan. Strategi coping adalah adalah salah satu faktor yang paling mempengaruhi SWT (Harma, 1993). Strategi coping yang mirip dengan pola hidup positif dapat meningkatkan kesehatan mental tenaga kesehatan. Beberapa hal yang bisa dilakukan oleh tenaga kesehatan diantaranya makan makanan sehat, melakukan aktivitas fisik, menjaga istirahat yang cukup walau sedang bekerja dalam sistem shift. Selain itu, tenaga kesehatan dianjurkan untuk menghindari perilaku berisiko tinggi seperti minum alkohol, pengunaan media sosial berlebihan karena hal tersebut dapat memberikan efek negatif bagi kesehatan mental tenaga kesehatan sehingga dapat menyebabkan kecemasan (Handayani, dkk., 2020).

Variabel kontak dengan pasien COVID-19 ditemukan tidak memiliki hubungan dengan kecemasan pada tenaga kesehatan. Hasil penelitian yang dilakukan di Trinidad dan Tribago mengemukakan bahwa kecemasan ditemukan sebagai gangguan kesehatan mental dengan prevalensi paling tinggi (56,2 persen) pada tenaga kesehatan. Dalam penelitian tersebut juga didapatkan hasil bahwa tenaga kesehatan yang pernah melakukan kontak dengan pasien COVID-19 ditemukan memiliki level stres yang rendah (Nayak, dkk., 2021). Dampak stres terhadap kesehatan memiliki kontribusi terhadap gangguan kesehatan mental seperti kelelahan dan kecemasan (International Labour Organization (ILO), 2016). Tidak adanya hubungan antara variabel kontak dengan pasien COVID-19 terhadap variabel tingkat kecemasan disebabkan oleh karena saat bekerja semua tenaga kesehatan diwajibkan untuk menggunakan APD.

Ketersediaan APD dalam penelitian ini diketahui tidak memiliki hubungan dengan kecemasan pada tenaga kesehatan. Hasil penelitian ini tidak sejalan dengan penelitian di Sidrap, Sulawesi Selatan yang menyimpulkan bahwa ketersediaan APD merupakan faktor yang memiliki pengaruh paling besar terhadap kecemasan tenaga kesehatan. Hal ini disebabkan responden dalam penelitian tersebut menjawab bahwa lokasi rumah sakit tempat mereka bekerja masih kekurangan persediaan APD. Kurangnya persediaan APD ini menyebabkan mereka merasa cemas saat akan bekerja (Fadli, dkk., 2020).

Hasil penelitian ini juga tidak sejalan dengan penelitian yang dilakukan di Provinsi Jilin, China oleh (Dong, dkk., 2021) yang mengemukakan bahwa ketersediaan APD memiliki hubungan yang signifikan terhadap tingkat kecemasan tenaga kesehatan di rumah sakit. Pemerintah DKI Jakarta telah melakukan distribusi APD untuk mengamankan persediaan APD di rumah sakit yang berada di DKI Jakarta. Salah satu rumah sakit yang menjadi penerima distribusi APD ini adalah RSUD Pasar Rebo, yang menjadi lokasi penelitian ini. Tidak adanya hubungan antara variabel ketersediaan APD dengan tingkat kecemasan pada tenaga Kesehatan mungkin disebabkan oleh banyaknya tenaga kesehatan yang menganggap bahwa RSUD Pasar Rebo telah menyediakan jumlah APD yang mencukupi bagi mereka.

\section{S I M P U L A N}

Berdasarkan hasil penelitian diketahui bahwa jenis kelamin, usia, status pernikahan, status memiliki anak, dan beban kerja memiliki hubungan dengan kecemasan pada tenaga kesehatan. Disarankan agar rumah sakit dapat memberikan layanan konseling, melakukan screening kesehatan mental tenaga kesehatan secara rutin. Penelitian ini tentunya memiliki keterbatasan, oleh karena itu disarankan bagi 
peneliti selanjutnya agar menggali lebih dalam mengenai faktor-faktor kecemasan tenaga kesehatan sehingga tidak terbatasa hanya variabel dalam penelitian ini.

\section{U C A P A N T ERIMA KASI H}

Penulis mengucapkan terima kasih kepada partisipan dalam penelitian ini yaitu tenaga kesehatan yang bekerja di RSUD Pasar Rebo, Jakarta Timur. Selain itu, peneliti mengucapkan terima kasih kepada pihak RSUD Pasar Rebo yang telah memberikan perizinan bagi peneliti dan RSUD Budhi Asih sebagai lokasi uji validitas dan reliabilitas kuesioner.

\section{DEKLARASI POTENSI TERJADINYA KONFLIK KEPENTINGAN}

Tyara Aderalda Deminanga, Azizah Musliha Fitri, Arga Buntara, dan Dyah Utari tidak bekerja, menjadi konsultan, memiliki saham, atau menerima dana dari perusahaan atau organisasi manapun yang mungkin akan mengambil untung dari diterbitkannya naskah ini.

\section{PUSTAKA ACUAN}

Alenazi, T. H., BinDhim, N. F., Alenazi, M. H., Tamim, H., Almagrabi, R. S., Aljohani, S. M., H Basyouni, M., Almubark, R. A., Althumiri, N. A., \& Alqahtani, S. A. (2020). Prevalence and predictors of anxiety among healthcare workers in Saudi Arabia during the COVID-19 pandemic. Journal of Infection and Public Health, 13(11), 1645-1651. https://doi.org/10.1016/j.jiph.2020.09.001

Anindyajati, G., Wiguna, T., Murtani, B. J., Christian, H., Wigantara, N. A., Putra, A. A., Hanafi, E., Minayati, K., Ismail, R. I., Kaligis, F., Savitri, A. I., Uiterwaal, C. S. P. M., \& Diatri, H. (2021). Anxiety and Its Associated Factors During the Initial Phase of the COVID-19 Pandemic in Indonesia. Frontiers in Psychiatry, 12, 634585. https://doi.org/10.3389/fpsyt.2021.634585

Arslanca, T., Fidan, C., Daggez, M., \& Dursun, P. (2021). Knowledge, preventive behaviors and risk perception of the COVID-19 pandemic: A cross-sectional study in Turkish health care workers. PLoS ONE, 16(4 April). https://doi.org/10.1371/journal.pone.0250017

Bao, Y., Sun, Y., Meng, S., Shi, J., \& Lu, L. (2020). 2019-nCoV epidemic: address mental health care to empower society. The Lancet, 395(10224), e37-e38. https://doi.org/10.1016/S0140$\underline{6736(20) 30309-3}$

Craske, M. G., Rauch, S. L., Ursano, R., Prenoveau, J., Pine, D. S., \& Zinbarg, R. E. (2011). What is an Anxiety Disorder? Focus, 9(3), 369-388. https://doi.org/10.1176/foc.9.3.foc369

Dong, H., Gao, J., Dong, Y.-X., Han, C., \& Sun, L. (2021). Prevalence of insomnia and anxiety among healthcare workers during the COVID-19 pandemic in Jilin Province. Brazilian Journal of Medical and Biological Research, 54(9), 1-9. https://doi.org/10.1590/1414-431x2020e10602

Evanoff, B. A., Strickland, J. R., Marie Dale, A., Hayibor, L., Page, E., Duncan, J. G., Kannampallil, T., Gray, D. L., \& Author, C. (2020). Work-Related and Personal Factors Associated with Mental Well-Being During the COVID-19 Response: Survey of Health Care and Other Workers. Journal Of Medical Internet Research, 22(8). https://doi.org/10.2196/21366

Fadli, F., Safruddin, S., Ahmad, A. S., Sumbara, S., \& Baharuddin, R. (2020). Faktor yang Mempengaruhi

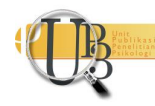


Kecemasan pada Tenaga Kesehatan Dalam Upaya Pencegahan COVID-19. Jurnal Pendidikan Keperawatan Indonesia, 6(1), 57-65. https://doi.org/10.17509/jpki.v6i1.24546

Handayani, R. T., Kuntari, S., Darmayanti, A. T., Widiyanto, A., \& Atmojo, J. T. (2020). Faktor Penyebab Stres Pada Tenaga Kesehatan Dan Masyarakat Saat Pandemi Covid-19. Jurnal Keperawatan Jiwa, 8(3), 353.

Handayani, R. T., Suminanto, Darmayanti, A. T., Widiyanto, A., \& Atmojo, J. T. (2020). Kondisi dan Strategi Penanganan Kecemasan Pada Tenaga Kesehatan Saat Pandemi COVID-19. International Journal of Africa Nursing Sciences, 3(3), 365-374. https://doi.org/10.1016/j.ijans.2020.100233

Hanggoro, A. Y., Suwarni, L., Selviana, \& Mawardi. (2020). Dampak Psikologis Pandemi COVID-19 pada Petugas Tenaga Kesehatan: A Studi Cross-Sectional di Kota Pontianak. Jurnal Kesehatan Masyarakat Indonesia, 15(2), 13-18.

Harma, M. (1993). Individual differences in tolerance to shiftwork: A review. Ergonomics, 36(1-3), 101-109. https://doi.org/10.1080/00140139308967860

International Labour Organization (ILO). (2016). Workplace Stress: a collective challenge. Diakses dari https://www.ilo.org/global/topics/safety-and-health-at-work/resourceslibrary/publications/WCMS 466547/lang--en/index.htm\%0Ahttp://www.ilo.org/africa/mediacentre/news/WCMS 477712/lang--en/index.htm

International Labour Organization (ILO). (2020). Managing work-related psychosocial risks during the COVID-19. Diakses dari https://www.ilo.org/global/topics/safety-and-health-at-work/resourceslibrary/publications/WCMS 748638/lang--en/index.htm

Jalnapulkar, I., Allen, M., \& Pigott, T. (2018). Sex Differences in Anxiety Disorders: A Review. HSOA Jurnal of Psychiatry, Depression \& Anxiety, 4, 1-4. https://doi.org/10.24966/pda-0150/100012

Jie, C., Xinghuang, L., Dongke, W., Yan, J., Miao, H., Yanling, M., Xiaolong, Z., Shuangning, S., Lei, Z., Xuelian, X., Ling, Y., Jun, S., Tao, B., \& Xiaohua, H. (2020). Risk factors for depression and anxiety in healthcare workers deployed during the COVID-19 outbreak in China. Social Psychiatry and Psychiatric Epidemiology, 56(1), 47-55. https://doi.org/10.1007/s00127-020-01954-1

Kamacooko, O., Kitonsa, J., Bahemuka, U. M., Kibengo, F. M., Wajja, A., Basajja, V., ... \& Ruzagira, E. (2021). Knowledge, Attitudes, and practices regarding COVID-19 among healthcare workers in Uganda: A cross-sectional survey. International journal of environmental research and public health, 18(13), 7004. https://doi.org/10.3390/ijerph18137004

Kementerian Kesehatan. (2020a). Protokol Pelayanan Dukungan Kesehatan Jiwa dan Psikososial bagi Petugas Kesehatan pada Pandemi Coronavirus Disease (Covid-19) di Fasilitas Pelayanan Kesehatan. Direktorat Pencegahan dan Pengendalian Masalah Kesehatan Jiwa dan NAPZA. Diakses dari https://covid19.go.id/p/protokol/protokol-pelayanan-dukungan-kesehatan-jiwa-danpsikososial-bagi-petugas-kesehatan-pada-pandemi-corona-virus-disease-covid-19-di-fasilitaspelayanan-kesehatan

Kementerian Kesehatan. (2020b). Keputusan Menteri Kesehatan Nomor HK.01.07/MENKES/447/2020 Mengenai Pemberian Insentif dan Santunan Kematian bagi Tenaga Kesehatan yang Menangani Coronavirus Disease 2019 (COVID-19). Diakses dari http://bppsdmk.kemkes.go.id/web/info/2695/Kepmenkes-Nomor-447-Tahun-2020-Tentang- 


\section{Pemberian-I}

Major, A., \& Hlubocky, F. J. (2021). Mental health of health care workers during the COVID-19 pandemic and evidence-based frameworks for mitigation: A rapid review. MedRxiv. http://medrxiv.org/content/early/2021/01/04/2021.01.03.21249166.abstract

Mattila, E., Peltokoski, J., Neva, M. H., Kaunonen, M., Helminen, M., \& Parkkila, A. K. (2021). COVID-19: anxiety among hospital staff and associated factors. Annals of Medicine, 53(1), 237-246. https://doi.org/10.1080/07853890.2020.1862905

Nayak, S., Sahu, P. K., Ramsaroop, K., Maharaj, S., Mootoo, W., Khan, S., \& Extavour, R. M. (2021). Prevalence and factors associated with depression, anxiety and stress among healthcare workers of Trinidad and Tobago during COVID-19 pandemic: a cross-sectional study. BMJ Open, 11, 44397. https://doi.org/10.1136/bmjopen-2020-044397

Noor, N. M., Yusof, R. C., \& Yacob, M. A. (2021). Anxiety in frontline and non-frontline healthcare providers in Kelantan, Malaysia. International Journal of Environmental Research and Public Health, 18(3), 1-10. https://doi.org/10.3390/ijerph18030861

Preti, E., Di Mattei, V., Perego, G., Ferrari, F., Mazzetti, M., Taranto, P., Di Pierro, R., Madeddu, F., \& Calati, R. (2020). The Psychological Impact of Epidemic and Pandemic Outbreaks on Healthcare Workers: Rapid Review of the Evidence. Current Psychiatry Reports, 22(8). https://doi.org/10.1007/s11920-020-01166-Z

Safaria, T. (2021). Psikologi Abnormal: Dasar-Dasar, Teori dan Aplikasinya (Budi Ashari (ed.)). UAD Press.

Satgas COVID-19. (2021). Peta Sebaran COVID-19. Diakses dari https://covid19.go.id/peta-sebarancovid19

Setiawati, Y., Wahyuhadi, J., Joestandari, F., Maramis, M. M., \& Atika, A. (2021). Anxiety and resilience of healthcare workers during COVID-19 pandemic in Indonesia. Journal of Multidisciplinary Healthcare, 14(January), 1-8. https://doi.org/10.2147/JMDH.S276655

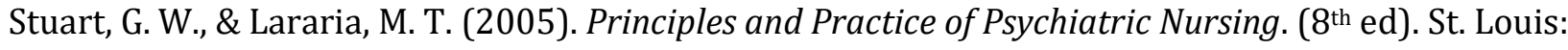
Mosby.

Tarwaka, Bakri, S. H. A., \& Sudiajeng, L. (2004). Ergonomi untuk Keselamatan, Kesehatan Kerja dan Produktivitas. Diakses dari http://shadibakri.uniba.ac.id/wp-content/uploads/2016/03/BukuErgonomi.pdf

Walton, M., Murray, E., \& Christian, M. D. (2020). Mental health care for medical staff and affiliated healthcare workers during the COVID-19 pandemic. European Heart Journal: Acute Cardiovascular Care, 9(3), 241-247. https://doi.org/10.1177/2048872620922795

World Health Organization (WHO). (2005). Health Policies and Programmes in the Workplace. Diakses dari https://apps.who.int/iris/handle/10665/205530

World Health Organization (WHO). (2020a). Coronavirus disease 2019 (COVID-19): situation report, 51. Diakses dari https://apps.who.int/iris/handle/10665/331475

World Health Organization (WHO). (2020b). Penggunaan rasional alat perlindungan diri untuk penyakit coronavirus (COVID-19) dan pertimbangan jika ketersediaan sangat terbatas. Diakses

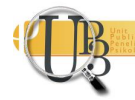


dari https://www.who.int/docs/default-source/searo/indonesia/covid19/who-2019penggunaan-rasional-alat-perlindungan-diri-untuk-covid-19-dan-

pertimbangan.pdf?sfvrsn=7eb7ebc7 2

Yildirim, T. T., Atas, O., Asafov, A., Yildirim, K., \& Balibey, H. (2020). Psychological Status of Healthcare Workers during the Covid-19 Pandemic. Journal of the College of Physicians and Surgeons Pakistan, 30, 26-31. https://doi.org/10.29271/icpsp.2020.Supp1.S26

Yuli Asih, G., Hardani Widhiastuti, Ms., \& Rusmalia Dewi, P. (2018). Stres Kerja. Semarang: Semarang University Press. 